\title{
TWITTER GAZETECILIĞi ILE ILGILI YAPILAN LISANSÜSTÜ TEZLERIN INCELENMESI
}

\author{
Muzaffer ŞAHIN*, Adalet GÖRGÜLÜ AYDOǦDU**
}

Gönderim Tarihi: 13.08.2020 - Kabul Tarihi: 25.09.2020

Şahin, M. ve Görgülü Aydoğdu, A. (2020). Twitter gazeteciliği ile ilgili yapılan lisansüstü tezlerin incelenmesi. Etkileşim, 6, 10-35. doi: 10.32739/etkilesim.2020.6.73

Bu çalışma araştırma ve yayın etiğine uygun olarak gerçekleştirilmiştir.

\section{Özet}

Twitter, özellikle gazetecinin haber kaynağını çeşitlendirmesi, haber kaynağına hızlıca ulaşabilmesi, haber iletimi, aktarımı, yayını ve habere yönelik feedback'leri izlemesi bakımından önemli yenilikler sağlamışır. Twittergünümüzde geleneksel medya araçlarının bir parçası olarak kullanılmasının yanı sıra gazetecilerin çalıştıkları medya kuruluşlarından bağımsız görünür olduğu kişisel bir alan olarak ön plana çıkmaktadır. Bu çalışmanın amacı Türkiye'de Twitter gazeteciliği ile ilgili yapılan lisansüstü tezleri incelemektir. Bu amaç doğrultusunda YÖK Tez Merkezi'nde yapılan tarama sonrasında konu ile ilgili 11 lisansüstü tez değerlendirmeye tabi tutulmuştur. Bu kapsamda Twitter gazeteciliği ile ilgili ne tür tezler yapıldığı, hangi yöntem ve veri hazırlama tekniklerinin kullanıldığı, hangi üniversitelerde bu konuya ağırlık verildiği tespit edilmeye çalışıımıştır. Doküman incelemesi ve içerik analizi tekniğinin kullanıldığı bu çalışma, konuya ilgi duyan akademisyenler için derleyici bir çalışma niteliği taşımaktadır. Çalışma sonucunda Twitter gazeteciliği ile ilgili yapılan tezlerin sayıca yeterli olmadığı, üniversitelerin bu konuya fazla eğilmediği, genelde Twitter kullanım pratiklerinin araştırıldığı, yeni yöntem ve veri toplama tekniklerine ihtiyaç bulunduğu gözlenmiştir.

Anahtar Kelimeler: gazetecilik, Twitter gazeteciliği, doküman incelemesi, lisansüstü tezler.

* Doçent Doktor, Ankara Hacı Bayram Veli Üniversitesi, illetişim Fakültesi, muzaffer.sahin@hbv.edu.tr, Orcid: 0000-0001-9589-3996

** Öğretim Görevlisi Doktor, Ankara Hacı Bayram Veli Üniversitesi, iletişim Fakültesi, adalet.gorgulu@hbv.edu.tr, Orcid: 0000-0001-6278-7214 


\title{
A REVIEW OF GRADUATE THESES ON TWITTER JOURNALISM
}

\author{
Muzaffer ŞAHIN*, Adalet GÖRGÜLÜ AYDOĞDU**
}

Received: 13.08.2020 - Accepted: 25.09.2020

Şahin, M. ve Görgülü Aydoğdu, A. (2020). Twitter gazeteciliği ile ilgili yapılan

lisansüstü tezlerin incelenmesi. Etkileşim, 6, 10-35. doi: 10.32739/etkilesim.2020.6.73

This study complies with research and publication ethics.

\begin{abstract}
Twitter has provided novelties for journalists in multiple aspects including diversification and rapid access to news sources, delivery, transfer, and broadcasting of news, and monitoring feedback. In addition to being used as a part of traditional media tools, Twitter has emerged as a personal space in which journalists are seen independent of the media organizations they work for. The purpose of this study is to review graduate theses completed in Turkey on Twitter journalism. In alignment with this purpose, a database search in YÖK (The Council of Higher Education) Thesis Center was completed which resulted in 11 graduate theses to be reviewed. Within this context, the types of theses completed on Twitter journalism, methodologies, and data management methods used, and the universities that place importance on this topic were explored. In this review, document and content analyses were used. The results of the study showed that the number of theses on Twitter journalism is not sufficient, that universities do not emphasize this topic, that the majority of the studies focus on the practices of Twitter use, and that new methods and data collection methods are needed.
\end{abstract}

Keywords: journalism, Twitter journalism, document analysis, graduate theses.

* Associate Professor, Ankara Hacı Bayram Veli University, Faculty of Communication, muzaffer.sahin@hbv.edu.tr, Orcid: 0000-0001-9589-3996

** Lecturer/PhD, Ankara Hacı Bayram Veli University, Faculty of Communication, adalet.gorgulu@hbv.edu.tr, Orcid: 0000-0001-6278-7214 


\section{Giriş}

Twitter, kullanıcılarının iletiler oluşturup gönderdiği ve oluşturulan içeriklerin başkaları tarafından yaygınlaştırılabildiği bir mikroblog hizmetidir. Başlangıçta kullanıcılarına "ne yapıyorsun?" sorusunu soran Twitter, Kasım 2009'da bu soruyu "neler olup bitiyor" şeklinde değiştirmiştir. Böylece 'gündelik gevezelik' olarak karakterize edilen "sandviç yiyorum" türünden tweet'lerden, haber medyasına doğru bir geçiş yapılmıştır (Rogers, 2016: 13, 17). Çevrim içi haberlerin gerçek zamanlı paylaşımını sağlarken, izleyiciye gazetecilerle doğrudan iletişim kurma imkânı veren Twitter (Keane ve Rodriguez, 2018: 75) aynı zamanda insanların olaylar hakkında neler düşündüklerini öğrenmek istediklerinde de ilk başvurdukları alan haline gelmiştir (Halavais, 2016: 79).

2006 yılında Amerikalı yazılım uzmanı Jack Dorsey tarafından geliştirilen Twitter, kullanıcılarına en fazla 140 karakterlik kısa iletiler (tweet'ler) paylaşma imkânı verirken, 2017 yılında iletilerdeki bu sınırı 280 karaktere çıkarmışıır. Son yıllarda URL'lerin otomatik olarak kısaltılması gibi çeşitli ek özelliklerin de dâhil edildiği Twitter, Facebook gibi diğer sosyal ağ sitelerinin aksine karşılıklı olmak zorunda değildir (Schmidt, 2016: 49).

Twitter günümüzde geleneksel medya araçlarının bir parçası olarak kullanılmasının yanı sıra gazetecilerin, çalıştıkları medya kuruluşlarından bağımsız görünür olduğu kişisel bir alan olarak ön plana çıkmaktadır. Twitter bir yandan gazetecilere mesleki anlamda potansiyel firsatlar sunarken, bir yandan da gazetecilik norm ve uygulamalarının değiştirilmesini gerekli hale getirmiştir. Twitter, özellikle gazetecinin haber kaynağını çeşitlendirmesi, haber kaynağına hızlıca ulaşabilmesi, haber iletimi, aktarımı, yayını ve habere yönelik 'feed-back'leri izlemesi bakımından önemli yenilikler sağlamıştır.

Twitter ortamında gazeteciliğin yeniden yapılandırıldığı bu gelişmeler yaşanırken, Twitter kullanıııları tarafından üretilen ve paylaşılan içerik de başta medya ve iletişim çalışmaları olmak üzere çeşitli disiplinler üzerinden yeni araştırma olanaklarına kapı açmaktadır (Weller vd. 2016: 35). Şahin ve Aydoğdu tarafından 2019 yılında yapılan "Twitter Gazeteciliği Çalışmaları" adlı araştırmada Web of Science veri tabanında 'Twitter gazeteciliği' ile ilgili toplam 151 yayın olduğu ve bu yayınların \% 47 'sini iletişim alanında yayınlanan çalışmaların oluşturduğu belirtilmiştir. Araştırmada ayrıca 2011 yılına kadar bu konuda fazla çalışmanın yapıımadığı, 2017 yılında bir düşüş yaşanmakla birlikte özellikle son yıllarda bu konuda yapılan çalışmaların arttığı ifade edilmektedir.

Bu çalışmanın amacı YÖK Tez Merkezi'nde yer alan Twitter ve gazetecilik bağlantılı lisansüstü tezlerin incelenmesidir. Bu doğrultuda çalışmada "Türkiye'de Twitter gazeteciliği bağlamında nasıl ve hangi konularda lisansüstü çalışmalar yapılmaktadır?", "Hangi üniversitelerde bu konuya daha fazla eğilim bulunmaktadır?", "Bu alanda yapılan lisansüstü tezlerde hangi yöntem ve veri toplama teknikleri kullanılmaktadır?" sorularına cevap aranmaktadır.

\section{2 etKileşim | Yıl3|Sayı 6| Ekim 2020}


Twitter ve gazetecilik bağlantılı lisansüstü tezlere, YÖK Tez Merkezi'nden erişilmiştir. Bu çalışma kapsamında YÖK Tez Merkezi'nde Twitter gazeteciliği alanında yapılmış lisansüstü tezler yıl sınırlaması getirilmeden incelenmiş ve konu ile ilgisi olmayan tezler inceleme kapsamına alınmamıştır. Tez Merkezi'nden ilgili aramalar 15.03.2020-20.03.2020 tarihleri arasında gerçekleştirilmiştir. Çalışma kapsamında YÖK Tez Merkezi'nde Twitter gazeteciliği anahtar kelimesi kullanılarak arama yapılmış ancak hiçbir çalışmaya rastlanılmamıştır. Bu nedenle Twitter ve gazetecilik bağlantılı olduğu belirlenen 11 lisansüstü tez değerlendirmeye alınmıştır.

Yükseköğretim Kurulu Başkanlığı bünyesinde bulunan Ulusal Tez Merkezi, 1987 yılından itibaren üniversitelerde yapılan yüksek lisans, doktora, sanatta yeterlik ve tıpta uzmanlık tezlerini toplayarak araştırmacıların hizmetine sunmaktadır. Yapılan tüm tezlerin toplandığı çevrimiçi bir veri tabanı olan Ulusal Tez Merkezi'nde 2019 yılı verilerine göre 600 binin üzerinde tez mevcuttur, kullanıcı sayısı ise 5.036.614'e ulaşmıştır (YÖK, 2020). YÖK Tez Merkezi'nde; Diş Hekimliği Uzmanlık 1254, Sanatta Yeterlik 1812, Tıpta Yan Dal Uzmanlık 776, Tıpta Uzmanlık 64612, Yüksek Lisans 433266 ve Doktora 106264 olmak üzere toplam 607984 çalışma bulunmaktadır (Yükseköğretim Kurulu Başkanlığı Tez Merkezi, 2020).

Lisansüstü eğitimin ürünü olan tez çalışmaları bir yandan araştırmacılara yol göstermekte, diğer yandan da bilimsel literatüre önemli katkılar sunmaktadır. Türkiye'de farklı alanlarda lisansüstü düzeyde yapılan tezlerin incelendiği pek çok araştırma yapılmasına rağmen (Koç, 2016; Büyükikiz, 2014; Aktan, 2014; Alpaydın ve Erol, 2017; Bayın, 2015; Özbey ve Şama, 2017; Alkan, 2014; Küçük Doğaroğlu, 2013; Beşel, 2017; Çakır Sümer, 2009; Uygun, 2012; Santaş, 2017; Gençel Ataman, 2009; Bayraktutan, 2015) Twitter ve gazetecilik bağlantılı tezlerin incelenmesi konusunda herhangi bir çalışma olmaması bu çalışmanın yapılmasında etkili olmuştur.

Bu çalışmada literatür incelemesinin ardından Twitter ve gazetecilik bağlantılı yapılmış lisansüstü tezlere ilişkin bulgulara yer verilmektedir. Türkiye'de Twitter gazeteciliği alanında ne tür çalışmalar yapıldığı, hangi yöntem ve analizlerin kullanıldığı, hangi üniversitelerin bu alana yoğunlaştıkları ile ilgili derleyici olan bu çalışmanın alanla ilgilenen araştırmacılara kolaylık sağlayacağı düşünülmektedir.

\section{Literatür İncelemesi}

Dünyada Twitter gazeteciliğine ilişkin pek çok çalışma yapılmıştır. Şahin ve Aydoğdu'nun (2019) da belirttiği gibi bu çalışmalarda daha çok Twitter'da şeffaflık, eşik bekçiliği ve normalleşme kavramları üzerinde durulmaktadır. Araştırmalar, gazetecilerin Twitter'ı bir haber kaynağı olarak kullandıklarını ve 
iş akışlarına entegre ettiklerini ortaya koymaktadır. Diğer yandan yapılan çaıışmalarda Twitter'ın habercilik pratiklerinde yoğun bir şekilde kullanılmasıyla birlikte şeffaflık normlarında ve geleneksel eşik bekçiliği rollerindeki değişime işaret edilmektedir (Keane ve Rodriguez, 2018; Leea vd. 2017; Groshek ve Tandoc, 2017; Tenenboim, 2017; Leuven ve Deprez, 2017; English, 2016; Powers ve Vera-Zambrano, 2018; Wihbey vd. 2019; Barnard, 2016; Bentivegna ve Marchetti, 2018; Larsson ve Moe, 2015; Engesser ve Humprecht, 2015; Hedman, 2015; Hanusch ve Nölleke, 2019; Jukes, 2019; Lasorsa vd. 2012; Canter, 2015; Liu vd. 2016; Revers, 2014; Thurman, 2018; Nordheim vd. 2018; Heravi ve Harrower, 2016).

Türkiye'de de son yıllarda Twitter gazeteciliğine yönelik akademik çalısmalar yapılmaya başlanmıştır. Arık (2013) tarafından yapılan çalışmada Twitter gazeteciliğinin temel dinamikleri analiz edilmiş ve yurttaş gazeteciliği ile arasındaki ilişki ele alınmıştır. Niteliksel tarihsel tasarım yöntemine göre yapılandırılan çalışmada, sıradan insanların da gazetecilik yapabilmeleri, seslerini duyurabilmeleri ve hak odaklı bir yayıncılık için son derece işlevsel bir araç olması nedeniyle Twitter'ın, yurttaş gazeteciliğinin temel zeminlerinden biri haline geldiği ifade edilmektedir. Yurttaş gazeteciliği için önemli bir işlevsel araca dönüşen Twitter, profesyonel gazeteciler için kişisel markalama ve kurumsal imajı güçlendirmeye aracılık etmektedir. Çaba ve Alemdar (2018) Twitter örneğinde gazetecilerin kişisel markalama çabasına odaklandıkları çalışmalarında, ana akım ve alternatif medyada yer alan gazetecilerin Twitter'da kendilerini nasıl tanıttıkları ve markalaştırdıklarına, gazetecilerin Twitter'ı kullanma pratikleri üzerinden sosyal medyanın geleneksel haber odası uygulamalarını nasıl dönüştürdüğüne yönelik araştırma yapmışlardır. Çalışmaya göre, ana akımda çalışan gazeteciler kendi kişisel markalarıyla beraber kurumlarının da imajını güçlendirme gayretinde oldukları için kişisel tanıtımı önemseyebilmekte, alternatif medyadaki gazeteciler ise ana akım gibi yüksek görünürlük düzeyine sahip olmadıkları için Twitter aracılığıyla seslerini duyurma çabasıyla kişisel tanıtımı öne çıkarabilmektedirler. Gazetecilerin kişisel markalama ve kurumsal imajlarının yanı sıra haber odaklı analizlerin de alana katkı sağlayacağı şüphesizdir.

Gazetecilerin sosyal medyayı alternatif bir medya olarak kullanımları, haber kaynağı olarak değerlendirmeleri ve haberleri yayma aracı olarak tercih etmeleri gibi profesyonel gazetecilik pratikleri de farklı çalışmalarda ele alınmıştır. Bakan (2017) çalışmasında gazetecilerin sosyal medyayı alternatif bir medya olarak kullanıp kullanmadıklarını incelemiştir. Bu kapsamda Washington Post'ta çalışan gazetecilerin çevrim içi köşe yazıları ve kişisel Twitter hesaplarındaki paylaşımları içerik açısından değerlendirilmiştir. Sosyal medyayı alternatif bir medya aracı olarak kullanma durumunun gazetecilere göre farklılık taşıdığının ortaya konulduğu çalışmada, gazetecilerin siyaset, uluslararası politika ve yasal düzenlemelerle ilgili konularda Twitter'ı alternatif bir medya

14 | 
olarak kullandıkları tespit edilmiştir. Sine ve Sarı da (2018) araştırmalarında bir haber kaynağı olarak sosyal medyanın gazeteciler için önemini tespit etmeyi amaçlamışlardır. Web tabanlı derinlemesine görüşme tekniği uygulanan araştırmada, sekiz medya profesyoneline sosyal medya hesaplarından canlı olarak sorular sorularak sosyal medyanın gazetecilik mesleğiyle ilişkisi saptanmaya çalışılmıştır. Çalışmanın sonunda görüşülen gazetecilerin tümünün sosyal medyayı haber kaynağı olarak kullandığı ortaya konulmuştur. Aral (2019) tarafından yapılan araştırmada ise internet gazetelerinin haberlerini sosyal medya hesaplarından ne ölçüde paylaştığının analiz edilmesi amaçlanmıştır. Bu kapsamda, örneklem olarak seçilen dört internet gazetesinin haber sayıları ile Facebook ve Twitter'daki paylaşımları karşılaştırılmıştır. Ayrıca internet gazetelerinin yöneticileri ile yüz yüze görüşmeler yapılarak çalışmaya ek veriler sağlanmıştır. Çalışma kapsamında elde edilen bulgularda, dört internet gazetesinin de Twitter'daki paylaşım sayısının Facebook'taki paylaşım sayısından fazla olduğu, Twitter'da haber akışının daha yoğun olduğu sonucuna ulaşılmıştır. Ayrıca internet gazetelerinin, sosyal medya hesaplarını okurların kullanım alışkanlıkları ve okur profilini gözeterek yönettikleri ifade edilen çalışmada, web sitesinde yayınlanan haberlerden Facebook ve Twitter'da paylaşılmak üzere seçim yapılacağı zaman, sadece belli bir kesime hitap etmeyen, geneli ilgilendirecek, okuru sıkmayacak haberlerin tercih edildiği belirtilmektedir. Haberlerin Twitter'da yayılma konusu ise ayrı bir çalışmada ele alınmıştır. Sütçü ve Bayrakçı (2014) gazetelerin haber kategorilerinde yer alan haberlerin Twitter'daki dağılımlarına bakarak gazete haberlerinin tweet edilme oranlarını araştırmışlardır. Geleneksel medya ile sosyal medya arasındaki haber yayılımı ilişkisinin incelendiği çalışma sonucunda haber web sitesinde çok yorum alan haberlerin sosyal medyada yayılımının daha yüksek olduğu tespit edilmiştir. Çalışmada, sosyal medyanın gazeteler için gelecekte var olmak isteyecekleri bir ortam olduğu ifade edilmiştir.

Gazetecilerin haber üretim aşamalarında Twitter üzerinden etkileşim süreçlerinin ele alındığı çalışmalarda gazetecilerin okurları-izleyicileri ile etkileşim düzeyleri ve süreçte haberin dönüşümü incelenmiştir. Çaba (2019), Türkiye'deki gazetecilerin Twitter'daki etkileşimine odaklandığı çalışmasında, gazetecilerin takipçileriyle etkileşimi ve içerikteki etkileşim düzeyi üzerinden gazetecilik uygulamalarındaki dönüşümü sorgulamıştır. Araştırmada farklı medya kuruluşlarında çalışan 21 gazetecinin tweet'leri analiz edilerek niteliksel ve niceliksel olarak değerlendirilmiş ve üç farklı gazeteci grubu -eşik bekçileri, muhabirler ve serbest gazeteciler- arasındaki farklılaşmanın ortaya konulması amaçlanmıştır. Çalışmada Twitter'ın etkileşimsel ağ ortamının olanaklarından en fazla serbest gazetecilerin yararlandığı, eşik bekçilerinin ise daha ziyade geleneksel medyadaki rollerini sürdürme eğilimi gösterdikleri görülmüştür. Uçar (2017) ise yaptığı çalışmada, Twitter'ın geleneksel medyanın profesyonel gazetecileri ile toplumun buluşmasına katkı sağladığı ifade edilerek, yurttaşları habere dâhil etme ve habercilik faaliyeti gerçekleştirme gibi pratiklerde 
aktif olarak rol alabildiği örneklerle anlatılmışır. Çalışmada geleneksel medyanın dikkatini çekmeyen olayların aktarımında yurttaşların, potansiyel birer gazeteci olarak paylaşımda bulunabildiği Twitter'ın, yurttaş gazeteciliğinin ruh bulduğu bir ortam sunarak, Twitter gazeteciliği gibi bir gazetecilik anlayışının literatüre girmesine neden olduğu belirtilmektedir. Kürkçü (2017) tarafından yapılan araştırmada da haber ajansları ve gazetelerden gelen iletilerin etkileşim düzeylerini belirlemek amacıyla Doğan Haber Ajansı (DHA), Anadolu Ajansı (AA), Sabah gazetesi, Sözcü gazetesi ve Hürriyet gazetesinin resmi Twitter hesaplarından paylaşılan tweet'ler incelenmiştir. Yapılan analizde haber tweet'lerinin 48 saat içindeki etkileşim oranları ve günün belli zaman dilimlerinde gönderilen tweet'lerin kullanıcılar tarafından ne kadar retweet edildiği ve beğenildiğiyle ilgili bilgiler verilmiş, tweet ve beğeni sayılarının toplam takipçi sayılarına oranları hesaplanarak kullanıcıların etkileşim düzeyleri belirlenmiştir.

Gazetecilerin Twitter'ı günlük iş akışlarının bir parçası olarak kullanmaları etik sorunları da beraberinde getirmiştir. Narin (2013) gazetecilik etiğini Twitter bağlamında ele alan çalışmasında, Twitter'da medya çalışanlarının paylaşımları ile birlikte gözlenen "yeni medya etiği" tartışmalarını literatür taraması yoluyla incelemiştir. Türkiye'de ulusal gazetelerin ve popüler gazetecilerin Twitter hesaplarına ilişkin sayısal bilgilerin de aktarıldı̆̆ı çalışmada, gazetecilik etiği bağlamında Twitter'ın kullanımına ilişkin temel sorunlar üzerinde durulmuştur. Çalışmada Türkiye'deki basın kuruluşları ve meslek örgütlerinin yeni etik düzenlemelere öncülük etmesi gerektiği vurgulanırken, bu düzenlemelerin kurumun ya da işvereninin itibarını ve kazancını olduğu kadar gazetecinin temel sorumluluk ve haklarını da koruma altına almasının gerekli olduğu belirtilmiştir.

Haber tüketicilerinin Twitter'ı haber aracı olarak kullanmalarına yönelik yapılan araştırmalarda ise tüketici tercihleri üzerinde durulmuştur. Bu bağlamda Kuyucu (2014), Twitter kullanıcılarının sosyal medya platformunu bir haber aracı olarak algı ve kullanımına yönelik yaptığı çalışmasında, Twitter'ın çevresel bir haber mecrası olarak yaygınlaştığını ve bireysel çıkışlı bir gazetecilik anlayışının geliştirildiğini belirtmiştir. Araştırmada Twitter kullanıcılarının günlük haber ihtiyaçlarını bu mecradan karşıladığı ve aynı zamanda haber üretimine de katkıda bulunduğu saptanmıştır.

Gazetecilik ve Twitter bağlamındaki çalışmaların kategorize edildiği bir başka eserde ise akademinin bu alandaki çalışmaları derlenmiştir. Hülür ve Yaşın'ın (2019) editörlüğünde hazırlanan Bilgi Doğruluk ve Twitter isimli eserde gazetecilik ile Twitter arasındaki ilişki kuramsal ve akademik çalışmalar bağlamında dokuz ayrı başlık altında, farklı yazarlar tarafından irdelenmiştir. Başlıklar şöyle sıralanmaktadır: "Küresel İnsanın Hayal Alanı Olarak Twitter'ı Anlamak", "Geçmişten Günümüze Bilgi ve Yöntemin Temelleri", "Epistemolojik Bir Tartışma: Twitter'da Doğruluk-Ötesi Konulu Çalışmalar", "Sahte Haber ve Twitter Hakkında Yapılmış Çalışmalar Üzerine Bir İnceleme", "Toplumsal Hare- 
ketlerin Twitter'a Yansımaları ve Hashtag Aktivizm ile ilgili Çalışmalar", "Twitter'ı Ele Alan Kriz iletişimi ve Kriz Yönetimi Çalışmalarının Analizi", "Twitter Gazeteciliği Çalışmaları", "Twitter ve Yeni Olanaklar: Sosyal Medyayla Birlikte Dönüşen Pazarlama ve Tüketim Biçimleri Üzerine Bir Literatür İncelemesi”, "Siyasal iletişim Süreçlerinde Yeni Illetişim Mecrası Olarak Twitter Kullanımı”.

\section{Yöntem}

Bu çalışmanın temel amacı YÖK Tez Merkezi'nde yer alan Twitterve gazetecilik bağlantılı konularda yapılan lisansüstü tezlerin incelenmesidir. Bu amaç doğrultusunda çalışmada YÖK Tez Merkezi üzerinden bir tarama gerçekleştirilmiş ve konu ile ilgili lisansüstü çalışmalar değerlendirmeye tabi tutulmuştur. "Twitter" başlığı ile YÖK Tez Merkezi'nde yapılan incelemede 133 yüksek lisans, 19 doktora tezine ulaşılmıştır. "Twitter gazeteciliği" anahtar kelimesi ile yapılan taramada herhangi bir teze rastlanmamıştır. Ancak "Twitter" anahtar kelimeli taramanın içinde gazetecilik bağlantılı olan dokuz yüksek lisans ve iki doktora tezi olmak üzere 11 teze erişim sağlanmıştır. Tez Merkezi'nden ilgili aramalar 15.03.2020-20.03.2020 tarihleri arasında gerçekleştirilmiştir.

Çalışmanın evrenini Twitter gazeteciliği alanındaki lisansüstü tezler oluşturmaktadır. Bu çalışmada örneklem belirleme yoluna gidilmemiş, bunun yerine veri tabanının sunduğu ilgili tezlerin tümüne ulaşılmaya çalışılmıştır. Böylece çalışma, araştırma evrenini oluşturan, biri hariç erişime açık tüm tezleri kapsayacak biçimde gerçekleştirilmiştir. Bu çalışma kapsamında YÖK Tez Merkezi'nde Twitter gazeteciliği alanında yapılmış lisansüstü tezler yıl sınırlaması gözetilmeksizin incelenmiş, konu ile ilgisi olmayan tezler ise çalışmanın kapsamı dışında bırakılmıştır.

Araştırmada, belge üzerinde doğrudan gözlem tekniği ile veri toplama yoluna gidilmiş olup elde edilen veriler içerik çözümlemesi tekniği ile incelenmiştir. Her bir tezin bir çözümleme birimi olarak alındığı içerik çözümlemesine temel oluşturan kategoriler ise inceleme konusu yapılan tezin yılı, tezin konusu, tezin yöntemi, tezde kullanılan veri toplama ve çözümleme teknikleri, tezin hangi üniversite ve program bünyesinde hazırlandığı biçiminde belirlenmiştir. Söz konusu birim ve kategoriler temel alınarak gerçekleştirilen kodlama işleminin ardından verilerin frekans dağılımları hesaplanmış ve tablolar oluşturularak elde edilen bulgular yorumlanmıştır.

\section{Bulgular}

Çalışmanın bu kısmında Yükseköğretim Kurulu Ulusal Tez Merkezi'nde kayıtlı Twitter ve gazetecilik bağlantılı tezlerden elde edilen bulgu ve yorumlar yer almaktadır: 
Tablo 1. Twitter ve gazetecilik bağlantılı yüksek lisans tezleri

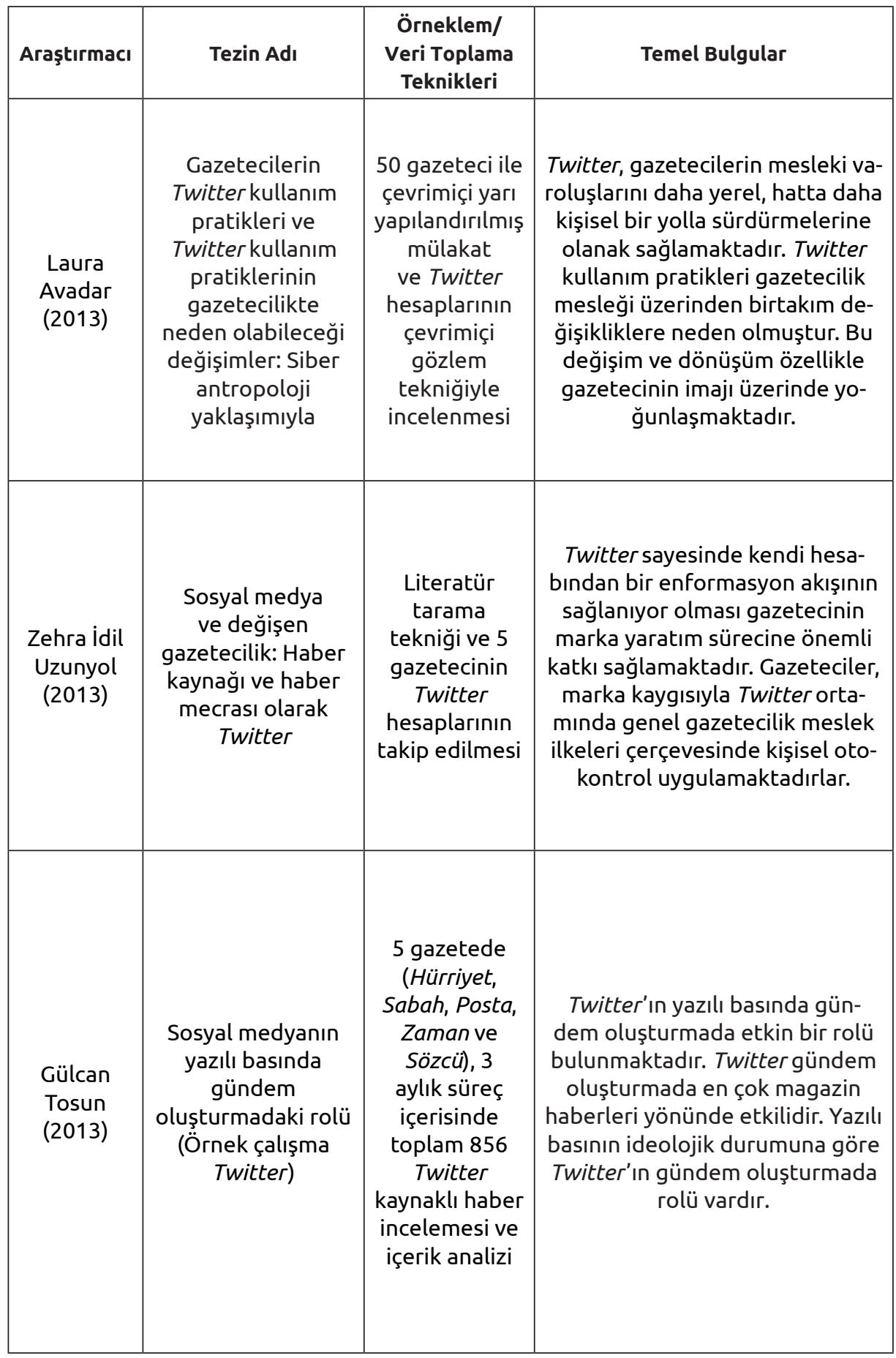

18 | EtKileşim | Yıl3|Sayı 6| Ekim 2020 


\begin{tabular}{|c|c|c|c|}
\hline $\begin{array}{l}\text { Necati } \\
\text { Keleş } \\
(2015)\end{array}$ & $\begin{array}{c}\text { Mısır'daki } \\
\text { toplumsal } \\
\text { hareketler ve } \\
\text { Anadolu Ajansı: } \\
\text { Örnek olay olarak } \\
\text { Anadolu Ajansı'nın } \\
\text { Twitter iletilerinin } \\
\text { analizi }\end{array}$ & $\begin{array}{l}507 \text { tweet, } \\
\text { nicel ve nitel } \\
\text { içerik analizi }\end{array}$ & $\begin{array}{c}\text { AA'nın, söz konusu dönemde } \\
\text { Türk dış politikasının öncelikli } \\
\text { konusu haline gelen Mısır'ı } \\
\text { önemli gündem maddelerinden } \\
\text { biri olarak gördüğü ve dış } \\
\text { politikaya hâkim olan söyleme } \\
\text { paralel yayın yaptığı ortaya ko- } \\
\text { nulmuştur. Anadolu Ajansı'nın, } \\
\text { Mısır'daki olayın, demokrasi, } \\
\text { insan hakları ve özgürlükler yö- } \\
\text { nünden yarattığı sorunları gün- } \\
\text { deme taşıdığı, AFP ve Reuters'e } \\
\text { göre Twitter'ı daha etkin kullan- } \\
\text { dığı görülmüştür. Twitter hesabı- } \\
\text { nı takip edenlerden söz konusu } \\
\text { tweet'lerle etkileşim kuranların } \\
\text { büyük çoğunluğunun, AA'nın bu } \\
\text { yayın politikasına olumlu yaklaş- } \\
\text { tığı tespit edilmiştir. }\end{array}$ \\
\hline $\begin{array}{l}\text { Hatice } \\
\text { Kübra } \\
\text { Kocaoğlu } \\
\text { (2015) }\end{array}$ & $\begin{array}{c}\text { Alternatif } \\
\text { haber kaynağı } \\
\text { olarak Twitter } \\
\text { ve gazeteciliğe } \\
\text { etkileri }\end{array}$ & $\begin{array}{c}\text { Türkiye'de } \\
\text { en çok satan } \\
\text { beş ulusal } \\
\text { ölçekli gazete } \\
\text { (Hürriyet, } \\
\text { Milliyet, Posta, } \\
\text { Sözcü, Zaman) } \\
\text { ile en çok } \\
\text { takip edilen } \\
\text { beş haber } \\
\text { sitesinin } \\
\text { (haberturk. } \\
\text { com, } \\
\text { hurriyet.com.tr, } \\
\text { internethaber. } \\
\text { com, } \\
\text { milliyet.com, } \\
\text { sabah.com.tr) } \\
\text { içerik analizi } \\
\text { ve meslek } \\
\text { profes- } \\
\text { yonelleri } \\
\text { ile mülakat } \\
\text { yapılması }\end{array}$ & $\begin{array}{c}\text { Haber kuruluşları için alternatif } \\
\text { bir haber kaynağı haline gelen } \\
\text { Twitter, aynı zamanda medya ku- } \\
\text { ruluşları ve gazeteciler açısından } \\
\text { da haberlerini servis edebildik- } \\
\text { leri bir mecraya evrilmiştir. Her } \\
\text { iki mecrada da Twitter kaynaklı } \\
\text { ve bağlantılı haberlerin, rutin } \\
\text { haber kapsamında öne çıktığı } \\
\text { görülmektedir. Her iki mecrada } \\
\text { da habercilik pratikleri açısından } \\
\text { büyük farklar olmadığı, Twitter } \\
\text { kaynaklı haberleri kullanmada, } \\
\text { kullanılan kategorilerin, habere } \\
\text { yaklaşımın, öne çıkan haber kay- } \\
\text { naklarının benzer olduğu dikkat } \\
\text { çekmektedir. En büyük farklılık } \\
\text { kullanılan görsel öğelerde orta- } \\
\text { ya çıkmaktadır. }\end{array}$ \\
\hline
\end{tabular}




\begin{tabular}{|c|c|c|c|}
\hline $\begin{array}{l}\text { Tahsin } \\
\text { Eren Sayar } \\
\quad(2016)\end{array}$ & $\begin{array}{c}\text { Türkiye'deki TV } \\
\text { haber kanallarının } \\
\text { yeni mecra olarak } \\
\text { Twitter'ı kullanımı }\end{array}$ & $\begin{array}{c}\text { TRT, Habertürk } \\
\text { ve Bianet } \\
\text { temsilcileri } \\
\text { ile Twitter } \\
\text { hesapları ile } \\
\text { ilgili mülakat } \\
\text { ve söylem } \\
\text { analizi }\end{array}$ & $\begin{array}{c}\text { Twitter ile haber kanalları ve } \\
\text { haber portalları ilişkisinin bir } \\
\text { karmaşıklık içerisinde olduğu } \\
\text { sonucuna varılmıştır. Kanalların } \\
\text { Twitter'a olan şüpheli yaklaşımı } \\
\text { devam etmektedir. Bu nedenle } \\
\text { kullanıcı kalitesinin artması ve } \\
\text { sahte hesapların engellenmesi- } \\
\text { nin Twitter'a olan güveni artıra- } \\
\text { cağı ön görülmektedir. }\end{array}$ \\
\hline $\begin{array}{l}\text { Valeria } \\
\text { Elosia } \\
\text { Moreno } \\
\text { Serrano } \\
(2017)\end{array}$ & $\begin{array}{c}\text { Spor gazetelerinin } \\
\text { Twitter kullanımları } \\
\text { üzerine bir çalışma: } \\
\text { Türkiye- Ekvador } \\
\text { karşılaştırması }\end{array}$ & $\begin{array}{c}\text { Fanatik ve El } \\
\text { Comercio spor } \\
\text { gazetelerinin } \\
\text { Twitter } \\
\text { hesaplarının } \\
\text { içerik } \\
\text { analizi ile } \\
\text { incelenmesi. } \\
\text { Derinle- } \\
\text { mesine bilgi } \\
\text { toplama ve } \\
\text { karşılaştırma } \\
\text { modeli } \\
\text { kullanılması }\end{array}$ & $\begin{array}{c}\text { Twitter, medya izleyicisiyle etkili } \\
\text { bir şekilde iletişim kurmada ve } \\
\text { en güncel bilgilerin hızlı bir şe- } \\
\text { kilde iletilmesi açısından önem } \\
\text { taşımaktadır. Her iki gazetenin } \\
\text { de hashtag kullandı̆ı̆ ve paylaş- } \\
\text { mış olduğu tweet'lere okuyu- } \\
\text { cular tarafından yanıt verildiği } \\
\text { görülmüştür. Her iki gazetenin } \\
\text { paylaşımlarının yoğunlaştığı } \\
\text { saatler arasında Türkiye ve Ek- } \\
\text { vador arasındaki zaman farkına } \\
\text { bağlı olarak, önemli değişiklikler } \\
\text { olduğu tespit edilmiştir. Bir } \\
\text { iletinin siber alanda daha fazla } \\
\text { paylaşılmasında yayın kalitesinin } \\
\text { içeriği ve öneminin yanı sıra o } \\
\text { iletinin multimedya kaynakları- } \\
\text { nın olup olmaması da önemlidir. }\end{array}$ \\
\hline $\begin{array}{c}\text { Seyit } \\
\text { Gölcük } \\
\text { (2018) }\end{array}$ & $\begin{array}{l}\text { Türkiye'de Twitter } \\
\text { bağlamında kendi } \\
\text { siyasi görüşüne } \\
\text { yakın haberleri } \\
\text { takip etme ve } \\
\text { siyasal kutuplaşma } \\
\text { ilişkisi }\end{array}$ & $\begin{array}{l}\text { Twitter'dan } \\
\text { çekilen } \\
2.790 .339 \\
\text { kişilik bir } \\
\text { örneklem } \\
\text { ve bu kişiler } \\
\text { arasındaki } \\
\text { toplam } \\
48.316 .548 \\
\text { farklı siyasi } \\
\text { haber ve } \\
\text { milletvekili } \\
\text { hesaplarını } \\
\text { takip etme } \\
\text { ilişkisinin } \\
\text { incelenmesi }\end{array}$ & $\begin{array}{c}\text { Bir partiye yakınlık duyan Twit- } \\
\text { ter kullanıcılarının kendi siyasi } \\
\text { görüşlerine yakın haber sitele- } \\
\text { rini yüksek derecede, kendi gö- } \\
\text { rüşlerine zıt fikirler içeren haber } \\
\text { sitelerine ait hesapları ise çok az } \\
\text { derecede takip ettikleri ortaya } \\
\text { konulmuştur. Ayrıca bu durumun } \\
\text { kutuplaşmayı tetiklediği de ifade } \\
\text { edilmektedir. }\end{array}$ \\
\hline
\end{tabular}

\section{0 |}




\begin{tabular}{|c|c|c|c|}
\hline $\begin{array}{c}\text { Mete } \\
\text { Ogün } \\
\text { Parlak } \\
(2019)\end{array}$ & $\begin{array}{c}\text { Yeni medya ve } \\
\text { haberciliğin } \\
\text { dönüşümü: } \\
\text { Gazetecilik mecrası } \\
\text { olarak Twitter }\end{array}$ & $\begin{array}{l}60 \text { gazeteciye } \\
\text { yüz yüze } \\
\text { anket } \\
\text { uygulaması } \\
\text { ve SPSS } \\
\text { programında } \\
\text { analizi }\end{array}$ & $\begin{array}{l}\text { İnternetin "etkileşimli" yapısı, } \\
\text { gazetecilerin haber tüketicisi ile } \\
\text { ilişkisinde belirleyici rol oyna- } \\
\text { maktadır. Gazeteciler gündemi } \\
\text { en fazla Twitter üzerinden takip } \\
\text { etmektedirler. Hızın öneminin } \\
\text { artması, gazetecilerin haber } \\
\text { içeriğini teyit etme pratiğini göz } \\
\text { ardı etmelerine neden olmak- } \\
\text { tadır. Tüm bu dönüşüm süreci, } \\
\text { beraberinde bu duruma uyum } \\
\text { sağlayabilecek ve yönetebilecek } \\
\text { gazetecilerin yetiştirilmesini } \\
\text { gerekli kılmaktadır. }\end{array}$ \\
\hline
\end{tabular}

Tablo 2. Twitter ve gazetecilik bağlantılı doktora tezleri

\begin{tabular}{|c|c|c|c|}
\hline Araştırmacı & Tezin Adı & $\begin{array}{c}\text { Örneklem/ } \\
\text { Veri Toplama } \\
\text { Teknikleri }\end{array}$ & Temel Bulgular \\
\hline $\begin{array}{l}\text { Gizem } \\
\text { Melek } \\
\text { (2015) }\end{array}$ & $\begin{array}{c}\text { Medya arası } \\
\text { gündem } \\
\text { belirleme kuramı } \\
\text { çerçevesinde } \\
\text { Hürriyet ve Twitter } \\
\text { üzerine bir çalışma }\end{array}$ & $\begin{array}{c}\text { Hürriyet } \\
\text { Online ve } \\
\text { Twitter } \\
\text { gündeminin } \\
\text { bilgisayar } \\
\text { destekli içerik } \\
\text { analizi ve } \\
\text { çapraz zaman } \\
\text { gecikmeli } \\
\text { panel } \\
\text { tasarımları ile } \\
\text { incelenmesi }\end{array}$ & $\begin{array}{l}\text { Ana akım medyanın eski gündem } \\
\text { belirleme gücüne sahip olmadığı } \\
\text { ve Twitter'ın da Türkiye'deki } \\
\text { popüler söylemde ifade edildiği } \\
\text { gibi bir gündem belirleme gücü } \\
\text { olmadığı ortaya konulmuştur. İki } \\
\text { medya arasında bir etkileşimin } \\
\text { olduğu belirtilmekte, haber } \\
\text { medyası ile sosyal medya arasın- } \\
\text { daki ilişki uluslararası bağlamda } \\
\text { benzer görülmektedir. }\end{array}$ \\
\hline
\end{tabular}




\begin{tabular}{|c|c|c|c|}
\hline $\begin{array}{l}\text { Aygün } \\
\text { Özsalih } \\
(2017)\end{array}$ & $\begin{array}{l}\text { Sosyal medyada } \\
\text { medyalar arası } \\
\text { gündem belirleme: } \\
\text { ABD ve Türkiye'de } \\
\text { Twitter örneği }\end{array}$ & $\begin{array}{c}\text { ABD ve Türki- } \\
\text { ye'de, üç bü- } \\
\text { yük gazetenin } \\
\text { Twitter he- } \\
\text { sapları örnek } \\
\text { alınarak, konu } \\
\text { gündemleri } \\
\text { arasında med- } \\
\text { yalar arası iliş- } \\
\text { ki ve etkilerin } \\
\text { içerik analizi, } \\
\text { Pearson } \\
\text { korelasyon } \\
\text { analizi ve çap- } \\
\text { raz-yürütmeli } \\
\text { korelasyon } \\
\text { analizi ile ince- } \\
\text { lenmesi }\end{array}$ & $\begin{array}{c}\text { ABD ve Türkiye'de, büyük ga- } \\
\text { zetelerin Twitter hesaplarının } \\
\text { konu gündemleri arasında med- } \\
\text { yalar arası ilişki ve etkilerinin } \\
\text { olduğu ortaya çıkmıştır. Her iki } \\
\text { ülke de medyalar arası gündem } \\
\text { belirleme bakımından birbirine } \\
\text { kısmen benzemektedir. Ayrıca, } \\
\text { ABD ve Türkiye'deki gazetelerin } \\
\text { Twitter gündemleri arasında } \\
\text { karşılıklı etkilere ilaveten tek } \\
\text { yönlü medyalar arası gündem } \\
\text { belirleme etkilerinin olduğu } \\
\text { görülmüştür. }\end{array}$ \\
\hline
\end{tabular}

Türkiye'de Twitter gazeteciliği ile ilgili lisansüstü çalışmaların 2013 yılından itibaren literatüre dâhil olduğu görülmektedir. İncelenen tezler, 2013-2019 yılları arasında değişkenlik göstermektedir. Türkiye'de Twittergazeteciliği ile ilgili yapılan yüksek lisans tezlerine bakıldığında en fazla tez çalışmasının 2013 yılında yapıldığı görülmektedir. 2013'te 3, 2015'te 2, 2016, 2017, 2018 ve 2019'da ise birer yüksek lisans tezi hazırlanmıştır. Bu tezlerin ikisi İngilizce, diğerleri Türkçedir. Yüksek lisans tezlerine oranla oldukça düşük bir sayıya sahip olan doktora tezlerinin ise 2015 (1) ve 2017 (1) yıllarında yapıldığı görülmektedir (Tablo 3).

Tablo 3. Lisansüstü tezlerin yıllara göre dağılımı

\begin{tabular}{|c|c|c|c|}
\hline Yıllar & Yüksek Lisans (n) & Doktora (n) & Yüzde (\%) \\
\hline 2013 & 3 & - & 27,3 \\
\hline 2014 & - & - & - \\
\hline 2015 & 2 & 1 & 27,3 \\
\hline 2016 & 1 & - & 9,1 \\
\hline 2017 & 1 & 1 & 18,1 \\
\hline 2018 & 1 & - & 9,1 \\
\hline 2019 & 1 & - & 9,1 \\
\hline Toplam & $\mathbf{9}$ & $\mathbf{2}$ & $\mathbf{1 0 0}$ \\
\hline
\end{tabular}

Genel olarak bakıldığında bu konuyla ilgili olarak 2013 (\%27,3) ve 2015 $(\% 27,3)$ yıllarında daha çok çalışma yapıldığı, son yıllarda ise daha az sayıda çalışma yapıldığı dikkat çekmektedir. 2014 yılında ise bu alanda yapılmış bir

22 | ETKiLeşim | Yıl3|Sayı6| Ekim 2020 
teze rastlanmamıştır (Tablo 3). Son yıllarda YÖK Tez Merkezi'nde tez sayısındaki (600 binden fazla) artışa rağmen Twitter gazeteciliği ile ilgili lisansüstü çalışmaların yeterli olmadığı ifade edilebilir.

Tablo 4. Lisansüstü çalışmaların konularına göre dağılımı

\begin{tabular}{|l|c|c|c|}
\hline \multicolumn{1}{|c|}{ Konular } & Yüksek Lisans (n) & Doktora (n) & Yüzde (\%) \\
\hline $\begin{array}{l}\text { Gazetecilerin Twitter } \\
\text { Kullanımı ve Haber Kaynağı } \\
\text { Olarak Twitter Kullanımı }\end{array}$ & 4 & - & 36,3 \\
\hline $\begin{array}{l}\text { Medya/Medyalar Arası Gün- } \\
\text { dem Belirleme Ilişkisi/Etkisi }\end{array}$ & 1 & 2 & 27,3 \\
\hline $\begin{array}{l}\text { TV kanallarının Twitter } \\
\text { Kullanımı }\end{array}$ & 1 & - & 9,1 \\
\hline $\begin{array}{l}\text { Spor Gazetelerinin Twitter } \\
\text { Kullanımı }\end{array}$ & 1 & - & 9,1 \\
\hline $\begin{array}{l}\text { Siyasal Iletişim Bağlamında } \\
\text { Twitter Kullanımı }\end{array}$ & 1 & - & 9,1 \\
\hline $\begin{array}{l}\text { Toplumsal Hareketler } \\
\text { Bağlamında Twitter Kul- } \\
\text { lanımı }\end{array}$ & 1 & $\mathbf{2}$ & $\mathbf{1 0 0}$ \\
\hline Toplam & $\mathbf{9}$ & & 9,1 \\
\hline
\end{tabular}

Hazırlanan tezlerin genellikle Twitter kullanımına yönelik yapıldığı belirlenmiştir. Bu çalışmalar ise konularına göre; gazetecilerin Twitter kullanımı ve haber kaynağı olarak Twitter kullanımı $(\% 36,3)$, medya/medyalararası gündem belirleme ilişkisi/etkisi bağlamında Twitter kullanımı $(\% 27,3)$, TV kanallarının Twitter kullanımı $(\% 9,1)$, spor gazetelerinin Twitter kullanımı $(\% 9,1)$, siyasal iletişim bağlamında Twitter kullanımı $(\% 9,1)$ ve toplumsal hareketler bağlamında Twitter kullanımı $(\% 9,1)$ olarak sınıflandırılabilir. Çalışmalar ana tema olarak altı ayrı kategoride tasnif edilmiş ve değerlendirmeler de bu odak üzerinden yapılmıştır (Tablo 4).

Gazetecilerin Twitterkullanımı ve haber kaynağı olarak Twitterkonusundaki çalışmalardan ilki Avadar'a aittir. Avadar (2013) çalışmasında, gazetecilerin Twitter kullanım pratikleri ile bu pratiklerin gazetecilik mesleğinde yol açtığı değişimleri ele almaktadır. Bu bağlamda araştırmada "Gazetecilerin Twitter kullanım pratikleri gazetecilik mesleğinde değişimlere yol açar" hipotezini doğrulamak amacıyla "Gazeteciler neden ve nasıl Twitter kullanıyorlar?", "Gazeteciler zamanının benzersiz iletişim araçlarından biri olan Twitter'ı kullanırken ne gibi pratikler geliştiriyorlar?" ve "Gazetecilerin Twitter kullanım pratikleri doğrultusunda gazetecilik mesleğinde değişimler meydana geliyor mu?" sorularına yanıt aranmıştır. Araştırma kapsamında Twitter'ı etkin bir biçimde kullanan 50 Türk gazeteciyle e-posta aracılığıyla çevrimiçi gerçekleştirilen yarı yapılandırılmış mülakatlar ve gazetecilerin Twitter hesapları gece ve gündüz takip edilerek yürütülen gözlemler doğrultusunda aydınlatılmaya çalışılmıştır. 
Siber antropoloji disiplini ile şekillendirilen çalışmada yapılan mülakat ve gözlem sonuçları, gazetecilerin Twitter kullanım pratiklerinin gazetecilik mesleği üzerinde birtakım değişikliklere neden olduğunu göstermiştir.

Bu konudaki çalışmalardan ikincisinde Uzunyol (2013) Twitter kullanımının gazetecilik pratiklerinde neden olduğu değişime odaklanmıştır. Çalışmada bütünsel bir yaklaşımla olaylar ve gelişmeler, neden ve sonuç ilişkisi içinde betimsel bir yöntemle araştırılmıştır. Temel olarak literatür tarama tekniği kullanılan çalışmada belirlenen gazetecilerin Twitter hesapları takip edilmiş ve yerli/yabancı medya kurumlarının sosyal medya kullanım kılavuzları incelenmiştir. İnternet ortamında ve yazılı medyada yer alan gazetecilerin Twitter kullanımına ilişkin tartışmaları taranmış, Wall Street Journal'ın teknoloji editörü ile mülakat yapılarak veri toplanmıştır. Araştırmada, Twitter sayesinde kendi hesabından bir enformasyon akışının sağlanıyor olmasının gazetecinin marka yaratım sürecine önemli katkı sağladığı ifade edilmektedir. Söz konusu gazetecilerin yine marka kaygısıyla Twitter ortamında genel gazetecilik meslek ilkeleri çerçevesinde kişisel otokontrol uyguladıklarını da gözlemlenmiştir.

Gazetecilerin Twitter kullanımı ve haber kaynağı olarak Twitter konusundaki çalışmalardan üçüncüsünü gerçekleştiren Kocaoğlu (2015) ise alternatif bir haber kaynağı olarak genelde sosyal medya, özelde Twitter'ın habercilik üzerinde oluşturduğu etkileri içerik analizi ve mülakat yöntemleri ile incelemiştir. Çalışmada geleneksel medya ve çevrimiçi haber sitelerinde yer alan Twitter kaynaklı ve bağlantılı haberler içerik çözümlemesine tabi tutulmuş, Twitter'ın yazılı basında ve internet gazeteciliğinde alternatif bir haber kaynağı olarak etkisi ölçülürken, bu bağlamda kaynaklık ettiği haberlerin çeşitli açılardan içerik değerlendirmesi de yapılmıştır. Elde edilen veriler doğrultusunda ulusal ölçekli gazeteler ve internet gazetelerinde Twitter kaynaklı haberlerin kullanımına karşılaştırmalı olarak yer verilmiştir. Mülakat yöntemiyle Twitter'ın gazetecilik meslek pratiklerine ve haber merkezi yapılarına olan etkisi irdelenmiştir. Haber kuruluşlarında çalışan gazetecilerle yapılan mülakatlarda; Twitter'ın haber üretim ve yayım sürecine etkileri, gazetecilik ve etik açısından sorunları, haber kuruluşlarındaki örgütlenme ve haber merkezi yapılarına etkisi ortaya konulmuştur.

Gazetecilerin haber kaynağı olarak Twitter konusundaki çalışmalardan dördüncüsünü hazırlayan Parlak (2019) Twitter özelinde internetin, gazetecilik mesleğindeki dönüştürücü etkisi üzerinde durmuştur. Bu çalışmada, internetin uygulama alanlarından biri olan sosyal medyanın, gazetecinin haber üretim pratiklerindeki yeri ve haberciliğin dijital platformlara taşınmasıyla oluşan gazeteci ile haber tüketicisi ilişkisindeki dönüşümün yansımaları incelenmiştir. Bu doğrultuda çalışma kapsamında veri toplama tekniği olarak, aktif biçimde habercilik mesleğini icra eden gazeteciler ile anket uygulaması gerçekleştirilmiş; Twitter özelinde gazetecilerin sosyal medyayı ne ölçüde haber kaynağı olarak gördükleri, sosyal medyadan haber üretiminde hangi düzeyde yararlandıkları ve haber tüketicisinin etkileşim faktörü temelinde sosyal medyanın

\section{4 etKileşim | Yıl3|Sayı 6| Ekim 2020}


haber üretimindeki yeni konumuna yaklaşımları irdelenmiştir.

Medya/medyalar arası gündem belirleme ilişkisi/etkisi konulu üç ayrı çalışma yapılmıştır. Bunlardan biri yüksek lisans, diğer ikisi doktora tezidir.

Tosun (2013) tarafından yapılan araştırma kapsamında Twitter'ın yazılı basınının gündemini oluşturmadaki rolü incelenmektedir. Çalışmayı kapsayan üç aylık süre içerisinde tiraj bazında ilk beş sırada yer alan gazeteler (Hürriyet, Sabah, Posta, Zaman ve Sözcü) incelenmiş ve 856 Twitter kaynaklı haber, araştırma kapsamına alınmıştır. Çalışmada, Twitter'ın yazılı basında gündem oluşturmadaki etkin bir rolü olduğu ortaya konulmaktadır. Twitter'ın gündem oluşturmada en çok magazin haberleri yönünde etkili olduğu belirtilmektedir.

Melek (2015) de çalışmasında Twitter'ın ana akım medyanın gündemini belirleme gücü olup olmadığını araştırmıştır. Hürriyet gazetesinin online haber sitesi (hurriyet.com.tr) ve Twitter'ın incelendiği çalışmada, öncelikle Pazardan Cumartesiye olmak üzere bir hafta boyunca sabah ve akşamları iki kez veriler toplanmıştır. Her iki medyada yapılan ön analiz doğrultusunda bir codebook oluşturulmuş ve bu codebook ile hem Hürriyet'e hem de Twitter'a aугı аугı içerik çözümlemesi yapılmıştır. Daha sonra medyalar arası gündem belirlemeyi test edebilmek için Rozelle-Campbell taban hizası ile çapraz zaman gecikmeli panel kullanılmıştır. Hürriyet ve Twitter arasında yedi günlük bir süreçte hem günler arasında hem de her günün özelinde karşıııklı bir medya arası gündem belirleme etkisi olduğunun varsayıldığı araştırma sonucunda, ana akım medyanın eski gündem belirleme gücüne sahip olmadığı ve Twitter'ın da Türkiye'deki popüler söylemde ifade edildiği gibi bir gündem belirleme gücü olmadığı ortaya konulmuştur. Çalışmada iki medya arasında bir etkileşimin olduğu belirtilirken, haber medyası ile sosyal medya arasındaki ilişki uluslararası bağlamda benzer görülmektedir.

Özsalih (2017) tarafından yapılan çalışmada ise daha önce geleneksel ve online medyalarda gerçekleşen medyalar arası gündem belirlemenin Twitter'da da gerçekleşip gerçekleşmeyeceği tespit edilmeye çalışıımıştır. ABD ve Türkiye'de üçer büyük gazetenin Twitter hesaplarının örnek alınarak yapıldığı çalışmada her iki ülkede de veriler içerik çözümlemesi ile toplanmış, haftalar itibariyle Pearson korelasyon analizi ile gazetelerin Twitter gündemleri arasındaki anlık ve otokorelasyonlar, çapraz-yürütmeli korelasyon çözümlemesi ile de etkiler ve nedensel ilişkiler ortaya konulmuştur. Çalışmada, ABD ve Türkiye'de, büyük gazetelerin Twitter hesapları konu gündemleri arasında medyalar arası ilişki ve etkilerin olduğu tespit edilmiştir. Ayrıca, çapraz korelasyonlardan yola çıkarak, ABD gazetelerinin Twitter gündemleri arasında karşııkl; Türkiye gazetelerinin Twitter gündemleri arasında ise karşılıklı etkilere ek olarak tek yönlü medyalar arası gündem belirleme etkilerinin olduğu görülmüştür. Çalışma sonucunda ABD ve Türkiye'nin medyalar arası gündem belirleme bakımından birbirine kısmen benzediği ortaya konulmuştur.

Televizyon kanallarının Twitter kullanımını inceleyen Sayar (2016) televiz- 
yon ve haber kanallarının sosyal medya ve tekelinde Twitter'ı kullanarak izleyiciye ne şekilde ulaştığını araştırmıştır. Çalışmada TRT Haber, Habertürk ve Bianet ile yapılan röportajlar ile kurum yöneticilerinin sosyal medya ve Twitter'a bakış açıları irdelenmiştir. Söylem çözümlemesi yapılan çalışma kapsamında yukarıdaki haber kanallarının Twitter kullanarak izleyiciye ulaşıp ulaşmak istemedikleri ve Twitter'dan haber paylaşımı sırasında ne tür kıstaslara önem verdiklerini öğrenmek amaçlanmıştır. Elde edilen bulgular ışığında kanalların Twitter'a olan şüpheli yaklaşımının sürdüğü görülmüştür. Bu nedenle kullanıcı kalitesinin artması ve sahte hesapların engellenmesinin Twitter'a olan güveni artıracağı öngörülmektedir.

Spor gazetelerinin Twitter kullanımı üzerine çalışan Moreno Serrano (2017) gazeteler, dolayısıyla gazetecilerin bu mecrayı nasıl ve ne sıklıkta kullandıkları irdelenmeye çalışılmıştır. Türkiye'den Fanatik, Ekvador'dan ise El Comercio spor gazetelerinin Twitter hesaplarının incelendiği araştırma, 2016 Rio Olimpiyat Oyunları döneminde yapılan paylaşımlarla sınırlı tutulmuştur. Sosyal medyanın, iletişim şekillerini değiştirmeye başladığının ifade edildiği çalışmada, bu değişimin gazetecilik özellikle de spor gazeteciliği alanında bir dönüşüme yol açtığı belirtilmektedir.

Siyasal iletişim bağlamında Twitter kullanımı ise Gölcük (2018) tarafından irdelenmiştir. Gölcük çalışmasında, Twitter'dan elde edilen özgün bir veri seti kullanılarak, kendi siyasi görüşüne yakın haberlere maruz kalma, siyasal kutuplaşma ve bu ikisi arasındaki istatistiksel ilişkiyi araştırmayı amaçlamıştır. Araştırmada Twitter'dan 2.790 .339 kişilik bir örneklem ve bu kişiler arasındaki toplam 48.316.548 farklı siyasi haber ve milletvekili hesaplarını takip etme ilişkisi çözümleme konusu edilmiştir. Bu çözümleme sonucunda bir partiye yakınlık duyan Türk Twitter kullanııılarının kendi siyasi görüşlerine yakın haber sitelerini yüksek derecede takip ettikleri, fakat kendi görüşlerine zıt fikirler içeren haber sitelerine ait hesapları çok az derecede takip ettikleri belirlenmiştir. Ayrıca bu kullanıııların, orantısız bir şekilde kendi görüşlerini temsil eden milletvekillerini takip etme ve yine orantısız bir şekilde kendi görüşlerine yakın popüler hesapları retweet etme bağlamında kutuplaştıkları görülmüştür. Çalışma, yakınlık hissedilen parti hangisi olursa olsun, yakın olunan ya da benimsenen görüşü destekleyen haberlerin kutuplaşmayı tetiklediğini, zıt görüşlü haberlerin ise partililerin kutuplaşmış tutumlarının azalmasına etki ettiğini göstermiştir.

Toplumsal hareketler bağlamında Twitter kullanımını çalışan Keleş (2015) Anadolu Ajansı'nın, Mısır'da ordunun yönetime el koyması sonrasındaki iki haftalık süreçte gelişmeleri aktarırken, Türk dış politikasına hâkim olan söyleme paralel yayın yapıp yapmadığını Twitter'daki içerikleri üzerinden incelemiştir. Anadolu Ajansı'nın resmi Twitter hesabından (@anadoluajansi) paylaşılan 507 tweet nicel ve nitel içerik çözümlemesiyle değerlendirilmiştir. Bu araştırmadan elde edilen bulgular, "AA'nın, söz konusu dönemde Türk dış politikasının öncelikli konusu haline gelen Mısır'ı önemli gündem maddelerinden biri olarak gördüğünü ve dış politikaya hâkim olan (darbe karşıtı ve Mursi yanlısı) söyleme 
paralel yayın yaptığını" ortaya koymuştur. Anadolu Ajansı'nın, Mısır'daki olayın, demokrasi, insan hakları ve özgürlükler yönünden yarattığı sorunları gündeme taşırken, AFP ve Reuters'e göre Twitter'ı daha etkin kullandığı görülmüştür. Twitter hesabını takip edenlerden söz konusu tweet'lerle etkileşim kuranların büyük çoğunluğunun, AA'nın bu yayın politikasına olumlu yaklaştığı tespit edilmiştir.

Tablo 5. Lisansüstü çalışmaların yönteme göre dağılımı

\begin{tabular}{|l|c|c|c|}
\hline & Yüksek Lisans (n) & Doktora (n) & Yüzde (\%) \\
\hline Nitel & 3 & - & 27,3 \\
\hline Nicel & 4 & 2 & 54,6 \\
\hline Karma & 2 & - & 18,1 \\
\hline Toplam & $\mathbf{9}$ & $\mathbf{2}$ & $\mathbf{1 0 0}$ \\
\hline
\end{tabular}

Twitterve gazetecilik ile ilgili yapılan lisansüstü çalışmaların yüzde 54,6'sını nicel çalışmalar oluştururken, yüzde 27,3'ü nitel, ve yüzde 18,1'i ise karma yöntemlerle yapılmıştır. Yıldız (2016: 416) bu durumu nicel araştırma yapmanın nitel araştırmaya kıyasla daha çok çalışma grubuna ulaşabilmeyi ve ölçmeyi kolaylaştırması ile açıklarken, Gaffney ve Puschmann (2016: 122) ise anket ve konvansiyonel içerik analizi gibi geleneksel araçların aksine, sosyal medya incelenirken, araştırmanın keşif evresinin bile belirgin bir şekilde nicel olduğunun altını çizmektedirler (Tablo 5).

Tablo 6. Lisansüstü çalışmaların veri toplama ve analiz tekniklerine göre dağılımı

\begin{tabular}{|l|c|c|c|}
\hline $\begin{array}{l}\text { Veri Toplama ve } \\
\text { Analiz Teknikleri }\end{array}$ & Yüksek Lisans (n) & Doktora (n) & Yüzde (\%) \\
\hline İçerik çözümlemesi & 6 & 2 & 50 \\
\hline Literatür tarama & 2 & - & 13 \\
\hline Mülakat & 3 & - & 19 \\
\hline Gözlem & 1 & - & 6 \\
\hline Söylem analizi & 1 & - & 6 \\
\hline Anket & 1 & - & 6 \\
\hline
\end{tabular}

İncelenen lisansüstü tezlerinin yüzde 50'sinde içerik çözümlemesi kullanılırken, yüzde 19'u mülakat, yüzde 13'ü literatür tarama, yani betimsel, yüzde 6'sı gözlem, yüzde 6'sı söylem çözümlemesi ve yüzde 6'sı anket uygulaması ile gerçekleştirilmiştir (Tablo 6). Ayrıca doktora tezlerinde içerik çözümlemesinin yanı sıra koreleasyon çözümlemesi ve Rozella Campbell taban hizası/ çapraz gecikmeli panel tasarımından da yararlanılmıştır. Tezlerin bir kısmında birden fazla teknik/yöntemin bir arada kullanıldığı görülmektedir. Diğer yandan çalışma kapsamında incelenen tezlerde örneklem/çalışma grubu genel olarak gazeteciler, gazeteler, gazete haber siteleri ve Twitter hesaplarından oluşmaktadır. 
Tablo 7. Lisansüstü çalışmaların üniversite ve anabilim dallarına göre dağılımı

\begin{tabular}{|l|c|c|c|c|}
\hline Üniversiteler & Enstitü & Anabilim Dalı & $\begin{array}{c}\text { Sayı } \\
\text { (n) }\end{array}$ & $\begin{array}{c}\text { Yüzde } \\
\text { (\%) }\end{array}$ \\
\hline $\begin{array}{l}\text { Galatasaray } \\
\text { Üniversitesi }\end{array}$ & SBE & Radyo Televizyon ve Sinema & 1 & 9,1 \\
\hline Ankara Üniversitesi & SBE & Gazetecilik & 2 & 18,1 \\
\hline $\begin{array}{l}\text { İstanbul Aydın } \\
\text { Üniversitesi }\end{array}$ & SBE & Halkla Ilişkiler ve Tanıtım & 1 & 9,1 \\
\hline Gazi Üniversitesi ${ }^{1}$ & SBE & Gazetecilik & 3 & 27,3 \\
\hline Marmara Üniversitesi & SBE & Radyo Televizyon ve Sinema & 1 & 9,1 \\
\hline ODTÜ & SBE & $\begin{array}{c}\text { Siyaset Bilimi ve } \\
\text { Kamu Yönetimi }\end{array}$ & 1 & 9,1 \\
\hline Ege Üniversitesi & SBE & Gazetecilik & 1 & 9,1 \\
\hline İstanbul Üniversitesi & SBE & Halkla Iilişkiler ve Tanıtım & 1 & 9,1 \\
\hline Toplam & & & $\mathbf{1 1}$ & $\mathbf{1 0 0}$ \\
\hline
\end{tabular}

Twitter ve gazetecilik bağlantılı tezlerin üniversitelere ve anabilim dallarına göre dağılımına bakıldığında en fazla sayıda tezin Gazi Üniversitesi Sosyal Bilimler Enstitüsü Gazetecilik Anabilim Dalında (\%27,3) yapıldığı görülmektedir. Bunu Ankara Üniversitesi Sosyal Bilimler Enstitüsü Gazetecilik Anabilim Dalı $(\% 18,1)$ takip etmektedir. Bu alanda lisansüstü tezlerin yapıldığı diğer üniversiteler ise Galatasaray, İstanbul Aydın, Marmara, İstanbul ve Orta Doğu Teknik üniversiteleridir. Bu konuyla ilgili Gazetecilik (6), Halkla ilişkiler ve Tanıtım (2), Radyo Televizyon ve Sinema Anabilim dallarının (2) yanı sıra Siyaset Bilimi ve Kamu Yönetimi Anabilim Dalında da (1) tez çalışması yapıldığı dikkati çekmektedir. Özellikle iletişimle ilgili alanlardaki yüksek lisans ve doktora programlarının sayısı düşünüldüğünde yapılan tez çalışmalarının sayıca yeterli olmadığı söylenebilir. Tezlerin sadece sekiz üniversite ile sınırlı kalması da düşündürücüdür. Yapılan çalışmaları devlet ve vakıf üniversitesi olarak değerlendirdiğimizde ise tezlerin biri hariç (İstanbul Aydın Üniversitesi) devlet üniversitelerinde yapıldığı görülmektedir (Tablo 7).

\section{Sonuç}

Twitter günümüzde gazetecilerin ve medya kuruluşlarının günlük mesleki rutinlerine dâhil ettikleri etkili bir araç haline gelmiştir. Twitter, özellikle gaze-

\footnotetext{
18 Mayıs 2018 tarihli ve 7141 sayılı Yükseköğretim Kanunu ile Bazı Kanun ve Kanun Hükmünde Kararnamelerde Değişiklik Yapılmasına Dair Kanunun 8. maddesi gereğince, Gazi Üniversitesi Sosyal Bilimler Enstitüsü kapatılmıştır ve ilgili anabilim dallarında kayıtlı olan lisansüstü öğrenciler, Ankara Hacı Bayram Veli Üniversitesi Lisansüstü Eğitim Enstitüsüne aktarılmışı̌r.
}

28 | ETKíleşim | Yıl3|Sayı 6 | Ekim 2020 
tecinin haber kaynağını çeşitlendirmesi, haber kaynağına hızlıca ulaşabilmesi, haberin üretim ve yayııımının yanı sıra habere yönelik feed-back'leri izlemesi bakımından önemli yenilikler getirmiştir. Gazetecilerin Twitter kullanımının gazetecilik mesleğinin pratikleri üzerinde yol açtığı değişimleri görebilmek ve gazeteciliğin hızla değişen bir dünyada gelişen rolünü daha iyi anlayabilmek için Twitter eksenli yapılacak olan çalışmalar önem taşımaktadır.

Bu çalışmada YÖK Tez Merkezi'nde yer alan Twitterve gazetecilik bağlantılı dokuz yüksek lisans, iki doktora tezi içerik çözümlemesi tekniği ile incelenmiştir. Ülkemizde Twitter gazeteciliği ile ilgili lisansüstü çalışmaların 2013 yılından itibaren başladığı görülmektedir. Türkiye'de Twitter gazeteciliği ile ilgili en fazla lisansüstü tez çalışması, bu alanda ilk çalışmaların yapıldığı 2013 yılına aittir. Türkiye'de ve dünyada Twitter'a olan ilginin ve kullanımın her geçen gün artmasına rağmen bu alanda yapılan çalışmalarda bir artış yaşanmamıştır. Twitter ve gazetecilik bağlantılı lisansüstü tezler incelendiğinde çok az sayıda çalışmanın doktora düzeyinde olduğu tespit edilmiştir. Bu durum henüz bu konuya yeterince önem verilmediğini göstermektedir. Lisansüstü tezlerde Twitter gazeteciliği ile ilgili çalışmalara ağırlık verilmesi ve öğrencilerin bu alanlarda farklı çalışmalar yapması teşvik edilmelidir.

Yapılan araştırmada incelenen lisansüstü tezlerin üniversitelere göre dağılımına bakıldığında; en fazla Gazi Üniversitesi Sosyal Bilimler Enstitüsü Gazetecilik Anabilim Dalı ve Ankara Üniversitesi Sosyal Bilimler Enstitüsü Gazetecilik Anabilim dalları bünyesinde gerçekleştirildiği belirlenmiştir. Bunun nedeni söz konusu üniversitelerin lisansüstü eğitimde belli bir geçmişe ve deneyime sahip olmaları ile açıklanabilir. Ancak Türkiye'de özellikle iletişim alanındaki lisansüstü programlarının sayısı dikkate alındığında bu konu ile ilgili yapılan tezlerin sayısının yeterli olmadığı söylenebilir. Ayrıca yapılan tezlerin belli üniversitelerle sınırlı kalması da ayrıca değerlendirilebilir. Yapılan çalışmaları devlet ve vakıf üniversitesi olarak değerlendirdiğimizde ise tezlerin biri hariç (istanbul Aydın Üniversitesi) tamamının devlet üniversitelerinde yapıldığı görülmektedir.

Konuları kapsamında değerlendirildiğinde ise yapılan tezlerin genellikle Twitter kullanımına yönelik yapıldığı ifade edilebilir. Bu çalışmalar; gazetecilerin Twitter kullanımı, haber kaynağı olarak Twitter kullanımı, medya/medyalar arası gündem belirleme ilişkisi/etkisi bağlamında Twitter kullanımı, TV kanallarının Twitter kullanımı, spor gazetelerinin Twitter kullanımı, siyasal iletişim bağlamında Twitter kullanımı ve toplumsal hareketler bağlamında Twitter kullanımı üzerine gerçekleştirilmiştir.

Twitter ve gazetecilik ile ilgili yapılan lisansüstü tezlerin büyük çoğunluğunda nicel yöntemler kullanılmıştır. İncelenen tezlerde en yaygın kullanılan araştırma ve analiz tekniği ise içerik analizidir. Bunun dışında yapılan tezlerde mülakat, literatür tarama, gözlem, anket tekniklerinin yanı sıra söylem çözümlemesi, koreleasyon çözümlemesi ve Rozella Campbell taban hizası/çapraz 
gecikmeli panel tasarımından da yararlanıldığı belirlenmiştir. Ayrıca çalışma kapsamında incelenen tezlerde çalışma grubu olarak gazeteciler, gazeteler, gazete haber siteleri ve Twitter hesapları ele alınmıştır.

Sonuç olarak, Twitter kullanıcı sayısı her geçen gün artmasına ve gazeteciler için yeni bir kapı aralamasına rağmen ülkemizde bu alanda yapılan lisansüstü tezlerin sayıca yeterli olmadığı görülmüştür. Twitter gibi etkin sosyal medya mecralarında yapılan araştırmalar, geleneksel medya üzerinden yapılan araştırmalara göre daha karmaşık bulunmaktadır. Bu nedenle araştırmacılar tarafından çok fazla tercih edilmediği söylenebilir. Ancak bu alanda dünyadaki gelişmeleri de takip ederek yeni yöntem ya da veri toplama teknikleri konusunda yeni yönelimlere ihtiyaç bulunmaktadır. Twitter haberciliği üzerinden yapılacak çözümleme ve incelemelerin artması araştırmacıların da bu alana yönelmesine neden olacaktır.

\section{Kaynakça}

Aktan, O. (2014). Stratejik planlama alanında yapılan lisansüstü tezlerin incelenmesi. Anadolu Ĕğitim Liderliği ve Öğretim Dergisi, 2(1), 12-31.

Alkan, G. (2014). Türkiye'de muhasebe alanında yapılan lisansüstü tez çalışmaları üzerine bir araştırma (1984-2012). Muhasebe ve Finansman Dergisi, 61, 41-52.

Alpaydın, Y. ve Erol, í. (2017). Türkiye'de eğitim ekonomisi alanında yapılan lisansüstü tezlerin incelenmesi. Marmara Üniversitesi Atatürk Eğitim Fakültesi Eğitim Bilimleri Dergisi, 45(45). 23-41.

Aral, E. (2019). Yeni bir haber mecrası olarak internet gazeteciliği: Facebook ve Twitter kullanımları üzerine bir araştırma. Maltepe Üniversitesi Iletişim Fakültesi Dergisi, 5(2),153-175.

Arık, E. (2013). Yurttaş gazeteciliğinin günümüzdeki görünümü: Twitter gazeteciliği örneği. Illetişim Kuram ve Araştırma Dergisi, 36, 273-287.

Avadar, L. (2013). Gazetecilerin Twitter kullanım pratikleri ve Twitter kullanım pratiklerinin gazetecilikte neden olabileceği değişimler: Siber antropoloji yaklaşımıyla (Yayımlanmamış yüksek lisans tezi). İstanbul: Galatasaray Üniversitesi Sosyal Bilimler Enstitüsü.

Bakan, U. (2017). Gazetecilerin alternatif bir medya olarak Twitter'ı kullanım düzeyi: Washington Post Örneği. Iletişim Kuram ve Araştırma Dergisi, 45, 263287.

Balcı, A. (2007). Sosyal bilimlerde araştırma yöntem, teknik ve ilkeler. Ankara: Pegem A Yayıncılık.

Barnard, S. R. (2016), Tweet or be sacked: Twitter and the new elements of journalistic practice. Journalism, 17(2), 190-207.

Bayın, G. (2015). Türkiye'de sağlık turizmi alanında yapılan lisansüstü tezlerin içerik değerlendirmesi. KMÜ Sosyal ve Ekonomik Araştırmalar Dergisi, 17(28), 4955 .

30 | ETkíteşim | Yı 3|Sayı 6| Ekim 2020 
Bayraktutan, G. (2015). İletişim araştırmalarında internet çalışmaları. B. Yıldırım (ed.), iletişim araştırmalarında yöntemler uygulama ve örneklerle. Konya: Literatürk Academia Yayınları.

Bentivegna, S. ve Marchetti, R. (2018). Journalists at a crossroads: Are traditional norms and practices challenged by Twitter?. Journalism, 19(2), 270-290.

Berelson, B. (1952). Content analysis in communication research. New York: Free Press.

Beşel, F. (2017). Türkiye'de maliye alanında yapılmış lisansüstü tezlerin bibliyometrik analizi (2003-2017). International Journal of Public Finance, 2(1), 27-62.

Büyükikiz, K. K. (2014), Yabancılara Türkçe öğretimi alanında hazırlanan lisansüstü tezler üzerine bir inceleme. Mustafa Kemal Üniversitesi Sosyal Bilimler Enstitüsü Dergisi, 11(25), 203-213.

Canter, L. (2015). Personalised tweeting: The emerging practices of journalists on Twitter. Digital Journalism, 3(6), 888-907.

Çaba, D. (2019), Sosyal medya çağında gazetecilik ve inovasyon: Twitter'da gazetecilik pratikleri üzerine bir analiz. Ankara Üniversitesi iLEF Dergisi, 6(1), 95120.

Çaba, D. ve Alemdar M. Y. (2018). Kişisel markalama bağlamında gazetecilerin Twitter kullanımı. 16th International Symposium Communication in the Millennium CIM 2018/April 25-28, (660-679).

Çakır Sümer, G. (2009). Türkiye'de yerel yönetimler yazınında çevre: Lisansüstü tezler üzerinden bibliyografik bir inceleme. C.Ü. Iktisadi ve idari Bilimler Dergisi, 10(2), 57-72.

Elosia Serrano, V. E. (2017). Spor gazetelerinin Twitter kullanımları üzerine bir çalışma: Türkiye- Ekvador karşılaştırması (Yayımlanmamış yüksek lisans tezi). Ankara: Gazi Üniversitesi Sosyal Bilimler Enstitüsü.

Engesser, S. ve Humprecht, E. (2015). Frequency or skillfulness: How professional news media use Twitter in five western countries. Journalism Studies, $16(4), 513-529$.

English, P. (2016). Twitter's diffusion in sports journalism: Role models, laggards and followers of the social media innovation. New Media \& Society, 18(3), 484-501.

Gaffney, D. ve Puschmann, C. (2016). Twitter'da veri koleksiyonları. K. Weller, A. Bruns, J. Burgess, M. Mahrt ve C. Puschmann (der.), Twitter ve toplum (E. Erbatur, çev.) (111-215). İstanbul: Kafka Epsilon Yayınları.

Gençel Ataman, Ö. (2009). Ülkemizde flüt ve flüt eğitimi alanlarında yapılan lisansüstü tezler. Kastamonu Eğitim Dergisi, 17(1), 341-352.

Gölcük, S. (2018). Türkiye'de Twitter bağlamında kendi siyasi görüşüne yakın haberleri takip etme ve siyasal kutuplaşma ilişkisi (Yayımlanmamış yüksek lisans tezi). Ankara: Orta Doğu Teknik Üniversitesi Sosyal Bilimler Enstitüsü. 
Groshek, J. ve Tandoc, E. (2017). The affordance effect: Gatekeeping and (Non) reciprocal journalism on Twitter. Computers in Human Behavior, 66, 201-210.

Halavais, A. (2016). Twitter'ın yapısı: Toplumsal ve teknik. K. Weller, A. Bruns, J. Burgess, M. Mahrt ve C. Puschmann (der.), Twitter ve Toplum (E. Erbatur, çev.) (79-95). İstanbul: Kafka Epsilon Yayınları.

Hanusch, F. ve Nölleke, D. (2019). Journalistic homophily on social media: Exploring journalists' interactions with each other on Twitter. Digital Journalism, 7(1), 22-44.

Hedman, U. (2015). J-tweeters pointing towards a new set of professional practices and norms in journalism. Digital Journalism, 3(2), 279-297.

Heravi, B. R. ve Harrower, N. (2016). Twitter journalism in Ireland: Sourcing and trust in the age of social media. Information, Communication \& Society, 19(9), 1194-1213.

Hülür, H. ve Yaşın, C. (2019). Bilgi, doğruluk ve Twitter. Ankara: Ütopya Yayınları.

Jukes, S. (2019). Crossing the line between news and the business of news: Exploring journalists' use of Twitter. Media and Communication, 7(1), 248-258.

Keane, M. T. ve Rodriguez, C. O. (2018). Attention to news and its dissemination on Twitter: A survey. Computer Science Review, 29, 74-94.

Keleş, N. (2015). Mısır'daki toplumsal hareketler ve Anadolu Ajansı: Örnek olay olarak Anadolu Ajansı'nın Twitter iletilerinin analizi (Yayımlanmamış yüksek lisans tezi). Ankara: Ankara Üniversitesi Sosyal Bilimler Enstitüsü.

Kocaoğlu, H. K. (2015). Alternatif haber kaynağı olarak Twitter ve gazeteciliğe etkileri (Yayımlanmamış yüksek lisans tezi). Ankara: Gazi Üniversitesi Sosyal Bilimler Enstitüsü.

Koç, E. S. (2016). Türkiye'de ilköğretim programlarının değerlendirilmesine yönelik yapılan lisansüstü tezlerin incelenmesi. Abant İzzet Baysal Üniversitesi Eğitim Fakültesi Dergisi, 16(1), 198-216.

Krippendorff, K. (2004). Content analysis: An introduction to its methodology. Sage Publications.

Kuyucu, M. (2014). Çevresel haber ortamı olarak Twitter ve Twitter gazeteciliği. Uluslararası Hakemli iletişim ve Edebiyat Araştırmaları Dergisi, 2(3), 159188.

Küçük Doğaroğlu, T. (2013). Türkiye'de dikkat eksikliği ve hiperaktivite bozukluğu ile ilgili çalışmaların yürütüldüğü lisansüstü tezlerin incelenmesi. Bilgisayar ve Eğitim Araştırmaları Dergisi, 1(2), 90-112.

Larsson, A. O. ve Moe, H. (2015). Bots or journalists? News sharing on Twitter. Communications: The European Journal of Communication Research, 40(3), 361370.

Lasorsa, D. L., Lewis, S. C. ve Holton, A. E. (2012). Normalizing Twitter: Journalism practice in an emerging communication space. Journalism Studies, 13(1), 19-36.

\section{2 | ETKíleşim | Yıl $3 \mid$ Sayı $6 \mid$ Ekim 2020}


Leea N. Y., Kimb Y. ve Sangc Y. (2017), How do journalists leverage Twitter? Expressive and consumptive use of Twitter. The Social Science Journal, 54(2), 13-147.

Leuven, S. V. ve Deprez, A. (2017). To follow or not to follow? How Belgian health journalists use Twitter to monitor potential sources. Journal of Applied Journalism \& Media Studies, 6(3), 545-566.

Liu, X., Li, Q., Nourbakhsh, A., Fang, R., Thomas, M., Anderson K., Kociuba R., Vedder, M., Pomerville, S., Wudali, R., Martin, R., Duprey, J., Vachher, A., Keenan, W. ve Shah, S. (2016). Reuters tracer: A large scale system of detecting \& verifying real-time news events from Twitter. 25th ACM International Conference on Information and Knowledge Management (CIKM), (207-216).

Melek, G. (2015). Medya arası gündem belirleme kuramı çerçevesinde Hürriyet ve Twitter üzerine bir çalışma (Yayımlanmamış doktora tezi). İzmir: Ege Üniversitesi Sosyal Bilimler Enstitüsü.

Narin, B. (2013). Medya ve gazetecilik etiği: Yemeğimi yedim, konsere gidiyorum. C. Bilgili ve G. Şener (ed.), Sosyal medya ve ağ toplumu-1: Kitle iletişiminde yaşanan değişimler (85-105). İstanbul: Reklam Yaratıcıları Derneği.

Nordheim, V. G., Boczek, K. ve Koppers L. (2018). Sourcing the sources: An analysis of the use of Twitter and Facebook as a journalistic source over 10 years in The New York Times, The Guardian, and Suddeutsche Zeitung. Digital Journalism, 6(7), 807-828.

Özbey, Ö. F. ve Şama, E. (2017). 2012-2016 arasındaki yıllarda çevre eğitimi kapsamında yayımlanan lisansüstü tezlerin incelenmesi. Bartın Üniversitesi Eğitim Fakültesi Dergisi, 6(1), 212-226.

Özsalih, A. (2017). Sosyal medyada medyalar arası gündem belirleme: ABD ve Türkiye'de Twitter örneği (Yayımlanmamış doktora tezi). İstanbul: İstanbul Üniversitesi Sosyal Bilimler Enstitüsü.

Parlak, M. O. (2019). Yeni medya ve haberciliğin dönüşümü: Gazetecilik mecrası olarak Twitter (Yayımlanmamış yüksek lisans tezi). Ankara: Gazi Üniversitesi Sosyal Bilimler Enstitüsü.

Powers, M. ve Vera-Zambrano, S. (2018). How journalists use social media in France and the United States: Analyzing technology use across journalistic fields. New Media \& Society, 20(8), 2728-2744.

Revers, M. (2014). The twitterization of news making: Transparency and journalistic professionalism. Journal of Communication, 64(5), 806-826.

Rogers, R. (2016). Twitter'ı sıradanlıktan kurtarmak. K. Weller, A. Bruns, J. Burgess, M. Mahrt ve C. Puschmann (der.), Twitter ve toplum. (E. Erbatur, çev.) (9-31). İstanbul: Kafka Epsilon Yayınları.

Santaş, F. (2017). Sağlık ekonomisi alanında yapılan lisansüstü tezlerin incelenmesi. Mehmet Akif Ersoy Üniversitesi Sosyal Bilimler Enstitüsü Dergisi, 9(19), 8593. 
Sayar, T. E. (2016). Türkiye'deki tv haber kanallarının yeni mecra olarak Twitter'ı kullanımı (Yayımlanmamış yüksek lisans tezi). İstanbul: Marmara Üniversitesi Sosyal Bilimler Enstitüsü.

Sayımer, İ. ve Çetinkaya, A. (2015). Alternatif medyanın Twitter'da gündem oluşturma süreci: Berkin Elvan olayı üzerine bir inceleme. S. Ersöz Karakulakoğlu ve Ö. Uğurlu (ed.), iletişim çalışmalarında dijital yaklaşımlar Twitter (225256). Ankara: Heretik Yayınları.

Schmidt, J. H. (2016). Twitter ve kişisel kamuların doğuşu. K. Weller, A. Bruns, J. Burgess, M. Mahrt ve C. Puschmann (der.), Twitter ve toplum (E. Erbatur, çev.) (47-61). İstanbul: Kafka Epsilon Yayınları.

Sine, R. ve Sarı, G. (2018). Profesyonel gazetecilerin gözünden sosyal medya ve habercilik ilişkisi. Akdeniz iletişim Dergisi, 30, 364-384.

Sütçü, C. S. ve Bayrakçı, S. (2014). Sosyal medya gazeteleri nasıl etkiliyor? Haberlerin Twitter'da yayılması üzerine bir araştırma. The Turkish Online Journal of Design, Art and Communication-TOJDAC, 4(2), 40-53.

Şahin, M. ve Görgülü Aydoğdu, A. (2019). Twitter gazeteciliği çalışmaları. H. Hülür ve C. Yaşin (ed.), Bilgi, doğruluk ve Twitter (184-216). Ankara: Ütopya Yayınevi.

Tenenboim, O. (2017). Reporting war in 140 characters: How journalists used Twitter during the 2014 Gaza-Israel conflict. International Journal of Communication, 11, 3497-3518.

Thurman, N. (2018). Social media, surveillance and news work: On the apps promising journalists a 'crystal ball'. Digital Journalism, 6(1), 76-97.

Tosun, G. (2013). Sosyal medyanın yazılı basında gündem oluşturmadaki rolü (Örnek çalışma Twitter) (Yayımlanmamış yüksek lisans tezi). İstanbul: İstanbul Aydın Üniversitesi Sosyal Bilimler Enstitüsü.

Uçar, A. K. (2017) Bir yurttaş gazeteciliği mecrası olarak yeni medya: Twitter örneği. Social Sciences Studies Journal, 3(8), 668-679.

Uygun, S. (2012). Eğitim tarihi alanında yapılmış lisansüstü tezlerin analizi. Erciyes Üniversitesi Sosyal Bilimler Enstitüsü Dergisi, 1(33), 263-282.

Uzunyol, Z. İ. (2013). Sosyal medya ve değişen gazetecilik: Haber kaynağı ve haber mecrası olarak Twitter (Yayımlanmamış yüksek lisans tezi). Ankara: Ankara Üniversitesi Sosyal Bilimler Enstitüsü.

Weller K., Bruns A., Burgess J., Mahrt M. ve Puschmann C. (2016). Twitter ve toplum: Giriş. K. Weller, A. Bruns, J. Burgess, M. Mahrt ve C. Puschmann (der.), Twitter ve toplum (E. Erbatur, çev.) (33-44). İstanbul: Kafka Epsilon Yayınları.

Wihbey J., Joseph, K. ve Lazer, D. (2019). The social silos of journalism? Twitter, news media and partisan segregation. New Media \& Society, 21(4), 815-835.

Yıldırım, A. ve Şimşek, H. (2008). Sosyal bilimlerde nitel araştırma yöntemleri. Ankara: Seçkin Yayınları.

\section{4 etKileşim | Yıl3|Sayı 6| Ekim 2020}


Yıldız, D. (2016). Uluslararası dil dergilerinde yayımlanan makalelerin amaç/konu ve yöntem açısından incelenmesi. Gazi Üniversitesi Gazi Eğitim Fakültesi Dergisi (GEFAD), 36(2), 399-425.

Yükseköğretim Kurulu. (2020). YÖK erişimi artırdı, ulusal tez merkezine ilgi arttı. https://acikerisim.yok.gov.tr/Sayfalar/Haberler/yok-ulusal-tez-merkezi-istatistikleri.aspx. 20 Mart 2020.

Yükseköğretim Kurulu Başkanlığı Tez Merkezi. (2020). İstatistiki bilgiler. https:// tez.yok.gov.tr/UlusalTezMerkezi/IstatistikiBilgiler?islem=4. 17 Mart 2020.

Çıkar çatışması : Çıkar çatışması bulunmamaktadır.

Finansal destek : Finansal destek bulunmamaktadır.

Conflict of interest : There are no conflicts of interest to declare.

Financial support: No funding was received for this study. 